\title{
KAITAN ASUPAN VITAMIN A DENGAN PRODUKSI AIR SUSU IBU (ASI) PADA IBU NIFAS
}

\author{
(Association between Vitamin A Intake with Breast Milk Production on Postpartum Mothers)
}

Bibi Ahmad Chahyanto ${ }^{1 *}$ dan Katrin Roosita ${ }^{1}$

'Departemen Gizi Masyarakat, Fakultas Ekologi Manusia (FEMA), Institut Pertanian Bogor, Bogor 16680

\begin{abstract}
This study aimed to analyze association between intake of vitamin A with breast milk production of postpartum mothers. A cross sectional study of 30 postpartum mothers was conducted in Ciherang, Sukawening, Dramaga, Sinarsari, and Neglasari Villages, Subdistrict of Dramaga, District of Bogor, during April to May 2013. Vitamin A intake of postpartum mothers from food source of vitamin $A$ was $565 \pm 351.40$ RE while sufficiency level of vitamin $A$ was $66.50 \pm 41.30 \%$. Most of postpartum mothers perceived that their breast milk production for infants were fulfilled (80\%). The results showed that vitamin A intake was significantly associated with breast milk production $(p<0.05)$. As intake of vitamin $A$ in postpartum mothers increased, breast milk production for infants would be fulfilled.
\end{abstract}

Keywords: breast milk, postpartum mother, vitamin A

\begin{abstract}
ABSTRAK
Penelitian ini bertujuan untuk menganalisis hubungan antara asupan vitamin A dengan produksi Air Susu Ibu (ASI) pada ibu nifas. Penelitian cross sectional ini melibatkan subjek penelitian sebanyak 30 ibu nifas di Desa Ciherang, Sukawening, Dramaga, Sinarsari, dan Neglasari, Kecamatan Dramaga, Kabupaten Bogor, pada bulan April hingga Mei 2013. Rata-rata asupan vitamin A dari seluruh pangan yang mengandung vitamin A sebesar $565 \pm 351.40$ RE dengan rata-rata tingkat kecukupan $66.50 \pm 41.30 \%$. Sebagian besar subjek memiliki produksi Air Susu Ibu yang cukup bagi bayinya (80\%). Hasil penelitian menunjukkan bahwa asupan vitamin A berhubungan signifikan dengan produksi ASI $(\mathrm{p}<0.05)$. Semakin tinggi asupan vitamin A pada ibu nifas, maka produksi Air Susu Ibu untuk bayi akan semakin tercukupi.
\end{abstract}

Kata kunci: air susu ibu, ibu nifas, vitamin A

"Korespondensi: Departemen Gizi Masyarakat, Fakultas Ekologi Manusia (FEMA), Institut Pertanian Bogor, Bogor 16680. Email: bibiahmadchahyanto@rocketmail.com 


\section{PENDAHULUAN}

Dewasa ini, banyak permasalahan kesehatan dan gizi di Indonesia khususnya pada bayi. Hal ini dibuktikan dengan tingginya prevalensi gizi kurang dan gizi buruk (Berat Badan/Umur) pada balita di Indonesia yakni 17.90\% (Riskesdas 2010).

Volume produksi Air Susu Ibu (ASI) merupakan salah satu faktor yang memengaruhi keberhasilan pemberian ASI eksklusif. Volume ASI yang diproduksi dipengaruhi oleh asupan gizi yang diperoleh ibu. Kebutuhan zat gizi ibu menyusui lebih besar dibanding ibu hamil yaitu penambahan energi (500 kkal pada enam bulan pertama dan 400 kkal pada bulan selanjutnya), protein ( $20 \mathrm{~g}$ ), dan konsumsi makanan sumber zat besi serta air yang cukup (Picciano 2003).

Vitamin A merupakan zat gizi mikro yang penting bagi ibu nifas. Vitamin A membantu hipofise anterior untuk merangsang sekresi hormon prolaktin di dalam epitel otak dan mengaktifkan sel-sel epitel pada alveoli untuk menampung air susu di dalam payudara (Soetarini et al. 2009).

Asupan vitamin A dari pangan pada perempuan di Indonesia hanya sepertiga dari jumlah yang dianjurkan. Pemenuhan vitamin A pada ibu nifas dilakukan pemerintah dengan memberikan dua kapsul vitamin A dosis tinggi (200 $000 \mathrm{SI}$ atau 60000 RE per kapsul). Fungsi pemberian kapsul vitamin A yang banyak diketahui ialah untuk mencegah kurang vitamin A baik pada balita maupun pada ibunya (Helen Keller International 2004). Untuk itu dalam penelitian ini, peneliti membuktikan fungsi lain dari vitamin A yakni dapat memengaruhi produksi ASI (Soetarini et al. 2009).

Penelitian ini bertujuan untuk 1) menghitung jumlah dan jenis konsumsi pangan dan asupan vita$\min A ; 2$ ) menilai kecukupan produksi ASI pada masa nifas; 3) menganalisis hubungan antara asupan vitamin A dengan produksi ASI pada ibu nifas.

\section{METODE}

\section{Desain, Tempat, dan Waktu}

Penelitian ini menggunakan desain cross sectional yang dilaksanakan di Desa Ciherang, Sukawening, Dramaga, Sinarsari, dan Neglasari, Kecamatan Dramaga, Kabupaten Bogor pada bulan April-Mei 2013. Tempat penelitian dipilih secara purposive yaitu sesuai dengan tujuan penelitian dengan mempertimbangkan lokasi, kemudahan akses dalam pengambilan data dan perizinan.

\section{Jumlah dan Cara Penarikan Subjek}

Subjek yang terpilih melalui teknik purposive, non probability quota sampling sebanyak 30 ibu nifas. Penarikan subjek dilakukan dengan mencari dan mengumpulkan ibu nifas yang memenuhi kriteria inklusi: 1) tidak termasuk wanita risiko tinggi ter- hadap risiko kematian dan kesakitan pada ibu dan bayi (berumur 20-35 tahun); 2) umur bayi 10-40 hari dan bukan kelahiran pertama; 3) bersedia menjadi subjek yang ditegaskan melalui informed consent; 4) subjek dalam keadaan sadar dan tidak mengalami gangguan kejiwaan; dan 5) bertempat tinggal di Desa Ciherang, Sukawening, Dramaga, Sinarsari, dan Neglasari, Kecamatan Dramaga, Kabupaten Bogor.

\section{Jenis dan Cara Pengumpulan Data}

Data yang dikumpulkan berupa data primer dan sekunder. Data primer yang diperoleh melalui wawancara terstruktur menggunakan kuesioner meliputi karakteristik subjek, keluarga, dan bayinya, konsumsi dan frekuensi konsumsi pangan, konsumsi kapsul vitamin A, serta persepsi kecukupan produksi ASI. Data berupa berat badan subjek dan bayinya diukur secara langsung dengan menggunakan timbangan injak ketelitian $0.10 \mathrm{~kg}$. Panjang LiLA (Lingkar Lengan Atas) subjek diukur menggunakan meteran ketelitian $0.10 \mathrm{~cm}$.

Data konsumsi makanan sumber vitamin A diperoleh melalui wawancara dengan metode food recall $2 \times 24$ jam. Food recall dilakukan pada dua hari yang berbeda dan tidak berurutan yaitu satu hari weekend (Sabtu atau Minggu) dan satu hari weekdays (Senin, Selasa, Rabu, atau Kamis). Food frequency questionnaire (FFQ) semi kuantitatif digunakan untuk mengetahui jenis dan jumlah makanan yang sering dikonsumsi selama masa nifas.

Data sekunder yang dikumpulkan berupa catatan ibu nifas yang diperoleh dari bidan desa dan gambaran umum wilayah serta kondisi sosial ekonomi penduduk yang diperoleh dari Kantor Kecamatan Dramaga dan Unit Pelayanan Teknis (UPT) Puskesmas Dramaga.

\section{Pengolahan dan Analisis Data}

Uji inferensia diawali dengan melakukan uji normalitas data menggunakan uji one sample Kolmogorov-Smirnov. Data penelitian yang digunakan untuk uji korelasi tersebar normal sehingga dapat dilakukan uji korelasi Spearman untuk menganalisis hubungan asupan vitamin A dengan produksi ASI. Nilai "p" yang didapatkan dari hasil uji korelasi dibandingkan dengan $\alpha=0.05$, hubungan antar variabel signifikan apabila nilai $p<0.05$.

\section{HASIL DAN PEMBAHASAN}

\section{Karakteristik Subjek, Keluarga, dan Bayi}

Karakteristik Subjek. Ibu nifas yang menjadi subjek dalam penelitian ini termasuk dalam wanita usia subur (umur 20-35 tahun) dengan rata-rata berumur $28.20 \pm 4.00$ tahun. Gunawan (2010) menyatakan bahwa umur ibu hamil di bawah 20 tahun memiliki risiko yang cukup tinggi untuk melahirkan 
bayi prematur dengan manifestasi klinis berat bayi lahir rendah, hypothermia, dan gagal nafas. Seluruh subjek sudah menempuh pendidikan dengan pendidikan terendah sekolah dasar (SD) dan tertinggi perguruan tinggi (PT). Firmansyah dan Mahmudah (2012) menyatakan bahwa pendidikan formal merupakan hal yang sangat penting dalam pembentukan pribadi dengan wawasan berfikir yang lebih baik. Semakin tinggi tingkat pendidikan formal, akan semakin luas pula cara berfikirnya.

Seluruh subjek tidak bekerja (ibu rumah tangga) dan sebanyak $83.30 \%$ termasuk multipara, sisanya (16.70\%) grade multipara. Ong et al. (2005), Foo et al. (2005), dan Rahmah (2008) menyatakan bahwa ibu yang tidak bekerja biasanya memiliki durasi pemberian ASI yang lebih lama dibandingkan dengan ibu yang bekerja. Kesulitan dalam membagi waktu antara pekerjaan dan pemberian ASI menjadi salah satu alasan bagi ibu bekerja untuk tidak memberikan ASI kepada bayinya secara cukup.

Sebanyak $93.30 \%$ subjek tidak berisiko kurang energi kronis (KEK) dengan LiLA $\geq 23.5 \mathrm{~cm}$, sisanya (6.70\%) berisiko KEK (LiLA $<23.5 \mathrm{~cm})$. Sebagian besar subjek $(76.70 \%$ dan $66.60 \%)$ termasuk kedalam tingkat kecukupan energi (TKE) dan protein (TKP) defisit berat (Tabel 1). Tingkat kecukupan energi dan protein yang dianalisis pada penelitian ini merupakan energi dan protein yang berasal dari pangan saja (tidak memperhitungkan lemak tubuh). Meskipun kondisi tubuh defisit energi dan protein dari pangan, risiko KEK bisa saja tidak ada (kecil persentasenya) karena tubuh akan memecah lemak yang ditimbun selama masa kehamilan menjadi energi untuk fungsi biologis tubuh termasuk menyusui.

Karakteristik Keluarga. Sebagian besar (70.00\%) keluarga subjek merupakan keluarga kecil (jumlah anggota keluarga $\leq 4$ orang). Pendapatan per kapita per bulan keluarga subjek berkisar antara Rp 75 000-Rp 625000 dengan rata-rata Rp 242 247士107 145. Setengah $(50.00 \%)$ dari subjek termasuk keluarga miskin (pendapatan per kapita per bulan $\leq \mathrm{Rp}$ 242 104). Sarbini dan Hidayati (2008), menyatakan bahwa tingkat pendapatan tidak memengaruhi pemberian ASI secara eksklusif.

Karakteristik Bayi. Umur bayi berkisar antara 10-36 hari dengan rata-rata $21.60 \pm 7.10$ hari. Hampir seluruh bayi subjek $(96.70 \%)$ lahir dengan berat lahir normal (2 $500 \mathrm{~g}-4000 \mathrm{~g}$ ).

\section{Konsumsi Pangan Sumber Vitamin A}

Jenis pangan nabati sumber vitamin A yang dikonsumsi subjek yaitu bayam, wortel, daun katuk, kangkung, sawi, tomat, daun singkong, dan ubi jalar merah. Sebanyak $93.30 \%$ subjek pernah mengonsumsi wortel dan bayam selama masa nifas (Tabel 2). Rata-rata frekuensi konsumsi wortel lebih tinggi dibanding bayam. Rata-rata frekuensi wortel $2.80 \pm 1.20 \mathrm{kali} /$ minggu dengan frekuensi konsumsi terbanyak tujuh kali/minggu, sedangkan rata-rata frekuensi konsumsi sayur bayam $2.50 \pm 1.00$ kali/ minggu dengan frekuensi konsumsi terbanyak empat kali/minggu.

Jenis pangan hewani sumber vitamin A yang dikonsumsi subjek yaitu daging ayam, telur ayam, susu bubuk, dan susu kental manis. Sebanyak $86.70 \%$ subjek mengonsumsi daging ayam dengan frekuensi konsumsi $2.00 \pm 1.50 \mathrm{kali} /$ minggu (Tabel 2 ).

Tabel 2. Distribusi Frekuensi Subjek berdasarkan Jenis Pangan Sumber Vitamin A yang Dikonsumsi

\begin{tabular}{lcc}
\hline Pangan Sumber Vit. A & $\mathrm{n}$ & $\%$ \\
\hline Pangan Nabati: & & \\
$\quad$ Bayam & 28 & 93.30 \\
Wortel & 28 & 93.30 \\
Daun katuk & 19 & 63.30 \\
Kangkung & 6 & 20.00 \\
Sawi & 4 & 13.30 \\
Tomat & 4 & 13.30 \\
Daun singkong & 1 & 3.30 \\
$\quad$ Ubi jalar merah & 4 & 13.30 \\
Pangan Hewani: & & \\
$\quad$ Daging ayam & 26 & 86.70 \\
$\quad$ Telur ayam & 20 & 66.70 \\
$\quad$ Susu bubuk & 5 & 16.70 \\
$\quad$ Susu kental manis & 3 & 10.00 \\
\hline
\end{tabular}

\section{Asupan Vitamin A}

Asupan vitamin A subjek berasal dari seluruh pangan yang dikonsumsi (seluruh pangan yang mengandung vitamin A) dan asupan vitamin A dari pangan sumber vitamin A. Rata-rata asupan vitamin A dari seluruh pangan yang mengandung vitamin A sebesar $565 \pm 351.40$ RE. Berdasarkan kelompok

Tabel 1. Sebaran Subjek berdasarkan Tingkat Kecukupan Zat Gizi

\begin{tabular}{lcccc}
\hline \multirow{2}{*}{ Kategori } & \multicolumn{2}{c}{ Tingkat Kecukupan Energi (TKE) } & \multicolumn{2}{c}{ Tingkat Kecukupan Protein (TKP) } \\
\cline { 2 - 5 } & $\mathrm{n}$ & $\%$ & $\mathrm{n}$ & $\%$ \\
\hline Defisit berat (TKE<70\%) & 23 & 76.70 & 20 & 66.60 \\
Defisit sedang (TKE 70-79\%) & 3 & 10.00 & 2 & 6.70 \\
Defisit ringan (TKE 80-89\%) & 2 & 6.70 & 2 & 6.70 \\
Normal (TKE 90-119\%) & 1 & 3.30 & 3 & 10.00 \\
Berlebih (TKE $\geq 120 \%)$ & 1 & 3.30 & 3 & 10.00 \\
\hline
\end{tabular}

JGP, Volume 8, Nomor 2, Juli 2013 
pangannya, rata-rata asupan vitamin A dari pangan nabati lebih tinggi $(462 \pm 367.00 \mathrm{RE})$ dibandingkan dengan asupan vitamin A dari pangan hewani $(103 \pm 116.00 \mathrm{RE})$ (Gambar 1).

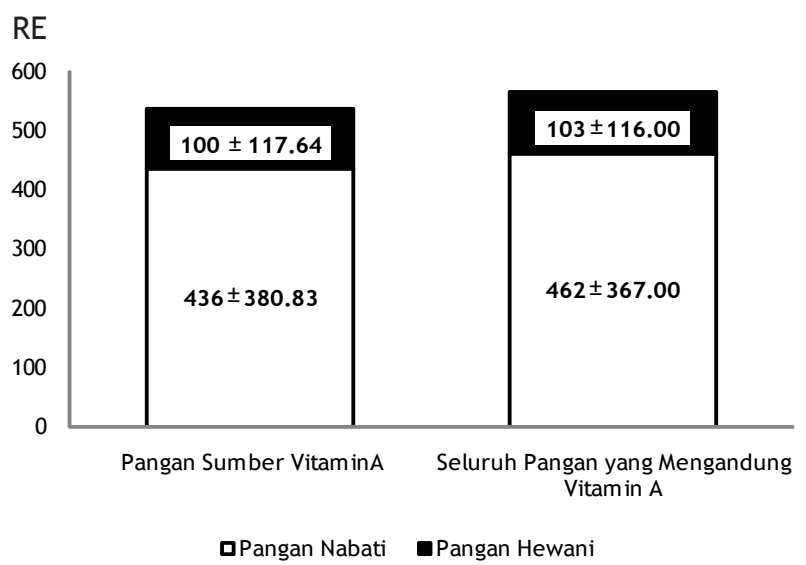

Gambar 1. Asupan Vitamin A berdasarkan Kelompok Pangan yang Dikonsumsi Subjek

Rata-rata asupan vitamin A dari pangan sumber vitamin A sebesar 536 $\pm 369.00 \mathrm{RE}$, dengan proporsi $436 \pm 380.83$ RE berasal dari pangan nabati, dan $100 \pm 116.00$ RE dari pangan hewani (Gambar 1). Rata-rata asupan vitamin A tertinggi untuk pangan nabati berasal dari bayam (163.73 RE), dan untuk pangan hewani berasal dari telur ayam (57.75 RE). Bayam dan telur ayam merupakan pangan yang mudah diolah serta terjangkau harganya. Selain itu, zat gizi yang terkandung dalam bayam dan telur juga cukup kompleks (termasuk vitamin A) sehingga bayam dan telur ayam menjadi alternatif makanan yang cukup baik dan cocok untuk ibu nifas. Vitamin A yang terkandung dalam bayam dan telur ayam cukup tinggi yakni 640.00 RE dan 309.00 RE per 100 gram.

Kecukupan vitamin A yang dianjurkan bagi ibu nifas selama enam bulan pertama dalam tabel AKG (2004) yang disepakati dalam WNPG (2004) ialah 850 RE. Hasil perbandingan rata-rata asupan vitamin A dengan kecukupan vitamin A yang dianjurkan menunjukkan bahwa rata-rata tingkat kecukupan vitamin A untuk seluruh pangan yang mengandung vitamin $A$ sebesar $66.50 \pm 41.30 \%$, sedangkan rata-rata tingkat kecukupan vitamin A untuk pangan sumber vitamin A sebesar $63.10 \pm 43.40 \%$. Berdasarkan kelompok pangannya, rata-rata tingkat kecukupan vitamin A dari pangan nabati lebih tinggi $(54.40 \pm 43.20 \%)$ dibandingkan dengan rata-rata tingkat kecukupan vitamin A dari pangan hewani (12.10ะ13.70\%) (Gambar 2). Hal ini mengindikasikan bahwa konsumsi pangan sehari-hari belum dapat menyumbangkan vitamin A yang cukup bagi kebutuhan vitamin A harian yang harus diasup oleh ibu nifas.

Seluruh subjek dalam penelitian ini sudah mengonsumsi dua kapsul vitamin A. Total asupan

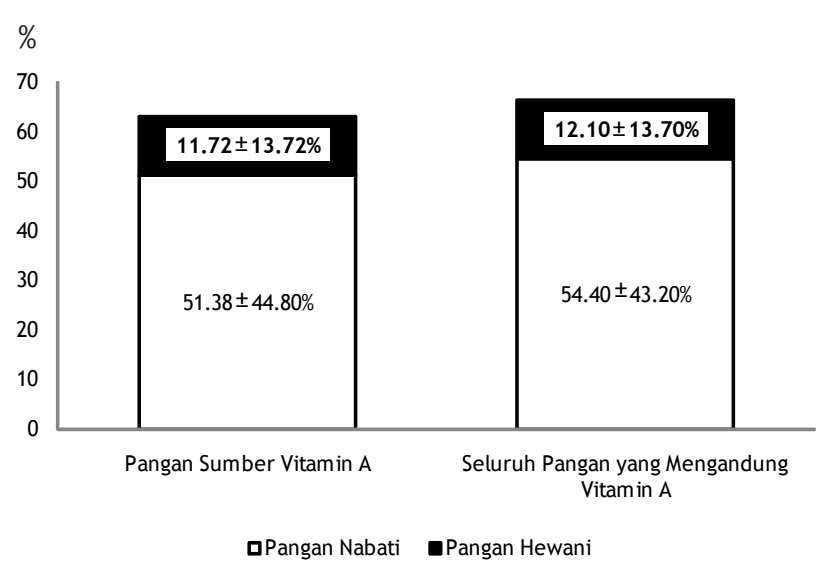

Gambar 2. Tingkat Kecukupan Vitamin A berdasarkan Kelompok Pangan yang Dikonsumsi Subjek

vitamin A dari kapsul sebesar 400000 SI (120 000 RE). Menurut Badan Kesehatan Dunia WHO dalam Helen Keller International (2004), ibu dan bayi akan mendapat manfaat dari pemberian kapsul vitamin A dosis tinggi hingga 180 hari (6 bulan) setelah melahirkan. Sehingga diduga vitamin A yang disumbangkan oleh kapsul untuk ibu nifas sebanyak $\pm 2000 \mathrm{SI}$ (650 RE) per hari dengan tingkat kecukupan vitamin A sebesar $76.50 \%$.

Tingkat kecukupan vitamin A dari kapsul (76.50\%) jika dijumlahkan dengan rata-rata tingkat kecukupan vitamin A dari seluruh pangan vitamin A (66.50\%), maka tingkat kecukupannya akan lebih dari sama dengan $77.00 \%$. Hal ini mengindikasikan bahwa apabila asupan vitamin A dari pangan kurang selama masa nifas, namun dibantu dengan konsumsi kapsul vitamin A program pemerintah, maka kebutuhan vitamin A harian akan tercukupi $(\geq 77.00 \%)$.

\section{Produksi ASI}

Kecukupan produksi ASI dikelompokkan menjadi tidak cukup (skor<3), kurang (skor 3-6), dan cukup (skor $>6$ ). Sebanyak $80.00 \%$ subjek memiliki produksi ASI yang cukup bagi bayinya, sisanya $(20.00 \%)$ kurang. Kecukupan produksi ASI dapat dibantu oleh asupan vitamin A. Selain itu, konsumsi jamu habis bersalin juga diduga dapat meningkatkan produksi ASI (Dahlianti et al. 2005; Roosita et al. 2003; Soetarini et al. 2009). Ahn dan Younblut (2007) serta Fang dan Hung (2012) menambahkan bahwa aspek lain seperti tingkat stres ibu juga dapat memengaruhi produksi ASI.

ASI sangat penting bagi bayi karena ASI makanan utama bagi bayi. ASI dikatakan cukup bagi bayi jika terdapat ciri-ciri antara lain ASI merembes keluar puting susu ibu, bayi menyusui lama $(>10$ menit) setiap kali menyusu, setelah menyusui bayi tidak rewel, dan bayi buang air kecil sering ( $>6$ kali) dalam sehari, ibu mendengar suara menelan ketika 
bayi menelan ASI, ibu merasa geli setiap kali bayi menyusu, anak menyusui lebih dari enam kali dalam sehari, bayi buang air besar lebih dari tiga kali dalam sehari (Kent et al. 2006).

\section{Hubungan Asupan Vitamin A dengan Produksi ASI}

Hasil uji Spearman menunjukkan terdapat hubungan yang signifikan antara asupan vitamin A dari pangan yang mengandung vitamin A maupun pangan sumber vitamin A saja dengan produksi ASI $(p<0.05)$. Hal ini berarti semakin tinggi konsumsi pangan sumber vitamin A, maka produksi ASI juga akan semakin tercukupi. Selain itu, konsumsi pangan yang memiliki kandungan vitamin A sedikit tetapi dikonsumsi dalam jumlah banyak juga dapat memengaruhi kecukupan produksi ASI.

Hasil penelitian ini sesuai dengan hasil penelitian Soetarini et al. (2009) di Polindes Kalisongo Dau Malang yang menyatakan bahwa terdapat pengaruh antara vitamin A terhadap pengeluaran ASI ibu postpartum. Hal ini karena vitamin A berfungsi dalam membantu produksi steroid (Almatsier 2006). Pidada et al. diacu dalam Marwah et al. (2010) menambahkan bahwa steroid dan vitamin A berperan merangsang proliferasi epitel alveolus sehingga akan terbentuk alveolus yang baru dan terjadi peningkatan jumlah alveolus dalam kelenjar ambing.

\section{KESIMPULAN}

Jenis pangan nabati sumber vitamin A yang dikonsumsi oleh subjek ialah bayam, wortel, daun katuk, kangkung, sawi, tomat, ubi jalar merah, dan daun singkong. Jenis pangan hewani sumber vitamin A yang banyak dikonsumsi oleh subjek ialah daging ayam, telur ayam, susu bubuk, dan susu kental manis. Rata-rata asupan vitamin A dari seluruh pangan yang mengandung vitamin A sebesar $565 \pm 351.40 \mathrm{RE}$ dengan rata-rata sumbangan $66.50 \pm 41.30 \%$, sedangkan rata-rata asupan vitamin A dari pangan sumber vitamin A sebesar $536 \pm 369.00$ RE dengan rata-rata sumbangan $63.10 \pm 43.40 \%$.

Konsumsi pangan sehari-hari belum dapat menyumbangkan vitamin $A$ yang cukup bagi kebutuhan vitamin A. Tingkat kecukupan zat gizi sebagian besar subjek masih defisit. Sebanyak $80.00 \%$ subjek memiliki produksi ASI yang cukup bagi bayi yang disusui. Terdapat hubungan yang signifikan antara asupan vitamin A dari pangan sumber vitamin A dan asupan vitamin $A$ dari seluruh pangan yang mengandung vitamin A dengan produksi ASI $(p<0.05)$.

Konsumsi pangan dan kapsul vitamin A memiliki manfaat yang penting bagi ibu nifas. Hal ini karena fungsi vitamin A yang dapat memengaruhi produksi Air Susu Ibu (ASI) pada ibu nifas. Untuk itu, sebaiknya asupan vitamin A baik dari seluruh pangan yang mengandung vitamin A dan pangan sumber vitamin A harus ditingkatkan sehingga asupan vitamin A tercukupi.

\section{DAFTAR PUSTAKA}

Ahn S \& Youngblut JM. 2007. Predictors of women's postpartum health status in the first 3 months after childbirth. Asian Nurs Research, 1(2), $136-146$.

Almatsier. 2006. Prinsip Dasar Ilmu Gizi. Gramedia Pustaka Utama, Jakarta.

Dahlianti R, Nasoetion A \& Roosita K. 2005. Keragaan perawatan kesehatan masa nifas, pola konsumsi jamu tradisional dan pengaruhnya pada ibu nifas di Desa Sukajadi, Kecamatan Tamansari, Bogor. Media Gizi dan Keluarga, 29 (2), 55-56.

Fang L \& Hung CH. 2012. Couple's postpartum health status. J Clin Nutr, 21, 2538-2544. doi: $10.1111 /$ j.1365-2702.2012.04104.

Firmansyah N \& Mahmudah. 2012. Pengaruh karakteristik (pendidikan, pekerjaan), pengetahuan dan sikap ibu menyusui terhadap pemberian ASI eksklusif di Kabupaten Tuban. Jurnal Biometrika dan Kependudukan, 1(1), 62-71.

Foo LL, Quek SJ, Ng SA, Lim MT \& Deurenberg YM. 2005. Breastfeeding prevalence and practices among Singaporean Chinese, Malay and Indian mothers. Healt Promot Int, 20(3), 229-37.

Gunawan AN. 2010. Pengaruh kehamilan di usia muda terhadap kelahiran prematur. Bul Penelitian RSUD Dr Soetomo, 12(4), 161-165.

Helen Keller International. 2004. Program pemberian kapsul vitamin A perlu ditingkatkan agar bermanfaat untuk ibu dan anak. Bul Kesehatan dan Gizi, 6(1), 1-4.

Kent JC, Mitoulas LR, Cregan MD, Ramsay DT, Doherty DA \& Hartmann PE. 2006. Volume and frequency of breastfeedings and fat content of breast milk throughout the day. Pediatrics, 117, e387. doi: 10. 1542/peds.2005-1417.

[Kemenkes RI] Kementrian Kesehatan RI. 2010. Riset Kesehatan Dasar (Riskesdas). Badan Penelitian dan Pengembangan Kesehatan Kemenkes RI, Jakarta.

Marwah MP, Suranindyah YY \& Murti TW. 2010. Produksi dan komposisi susu kambing peranakan ettawa yang diberi suplemen daun katuk (Sauropus androgynus (L) Merr) pada awal masa laktasi. Bul Peternakan, 34(2), 94-102.

Ong G, Yap M, Li FL \& Choo TB. 2005. Impact of working status on breastfeeding in Singapore: evidence from the National Breastfeeding Survey 2001. Eur J Public Health, 15(4), 424-30. doi: 10.1093/eurpub/cki030. 
Picciano MF. 2003. Pregnancy and lactation: physiological adjustments, nutritional requirements and the role of dietary supplements. J Nutr, 133: 1997s - 2002s. doi:0022-3166/03.

Rahmah L. 2008. Atribusi tentang kegagalan pemberian ASI pada ibu pekerja. Proyeksi, 6(1), $62-70$.

Roosita K, Kusumorini N, Manalu W, \& Kusharto CM. 2003. Efek jamu bersalin galohgor terhadap involusi uterus dan gambaran darah tikus (Rattus sp). Media Gizi dan Keluarga, 27(2), 52-57.
Sarbini D \& Hidayati D. 2008. Hubungan antara tingkat pendapatan keluarga dan pendidikan ibu dengan pemberian ASI eksklusif di Kecamatan Jebres Kotamadya Surakarta. J Kesh, 1(2), 115-122.

Soetarini E, Yulifah R \& Wirastuti A. 2009. Pemberian vitamin $A$ dengan pengeluaran air susu ibu Post Partum di Polindes Kalisongo Dau Malang. J Kes, 7(2), 96-99.

[WNPG] Widyakarya Nasional Pangan dan Gizi. 2004. Ketahanan Pangan dan Gizi di Era Otonomi Daerah dan Globalisasi. LIPI. Jakarta. 